\title{
THE SENATE'S PIE-IN-THE-SKY TREATY INTERPRETATION: POWER AND THE QUEST FOR LEGISLATIVE SUPREMACY*
}

\author{
Lawrence J. Block, $\dagger$ Lee A. Casey $\dagger \dagger$ \& David B. Rivkin, \\ JR. $+\dagger^{\dagger}$
}

\section{INTRODUCTION}

The debate over ABM Treaty interpretation and reinterpretation into which Professor Koplow ventures is part and parcel of two much broader and dramatic confrontations: the struggle currently being waged over the direction of United States nuclear strategy and a battle between the Executive and the Congress over the formulation and implementation of American foreign policy.' Unfortunately, this broad policy context for treaty power disputes, far from helping to illuminate the underlying constitutional issues, appears to have injected passion, partisanship, ${ }^{2}$ and strongly held doctrinal predilections into the discus-

* The views contained herein are those of the authors and do not necessarily represent the positions of the Department of Justice or of any other agency of the United States Government.

† Senior-Attorney Advisor, Office of Policy Development, United States Department of Justice; B.S., University College, New York University, 1976; J.D., The John Marshall Law School, 1981.

H Senior-Attorney Advisor, Office of Policy Development, United States Department of Justice; B.A., Oakland University, Rochester, Michigan, 1979; J.D., University of Michigan Law School, 1982.

Ht Senior-Attorney Advisor, Office of Policy Development, United States Department of Justice; B.S.F.S. and M.S., Georgetown University School of Foreign Service, 1980, 1983; J.D., Columbia University School of Law, 1985.

1 The connection between the constitutional and policy issues has been acknowledged by the proponents of the Senate's alleged treaty interpretation prerogatives. Senator Biden (D.-Del.) has noted as follows: "We are witnessing a major assault on the premises and structure of a national nuclear strategy .... [and] a subtle but equally significant assault on the Constitution's allocation of the treaty power." The ABM Treaty and the Constitution: Joint Hearings Before the Senate Comm. on Foreign Relations and the Senate Comm. on the Judiciary, 100th Cong., 1st Sess. 263 (1987), quoted in Koplow, Constitutional Bait and Switch: Executive Reinterpretation of Arms Control Treaties, 137 U. PA. L. REv. 1353, 1356 n.6 (1989).

2 For example, with characteristic understatement, the Democratic majority of the Senate Foreign Relations Committee termed the efforts of the Reagan Administration to review and reinterpret certain sections of the 1972 ABM Treaty "the most flagrant abuse of the Constitution's treaty power in 200 years of American history." SENATE COMM. ON ForEIgN ReLATIONS, THE ABM TREATY INTERPRETATION RESOLUTION, S. ReP. No. 164, 100th Cong., 1st Sess. 66 (1987) [hereinafter ABM TrEaTY REPORT], quoted in Koplow, supra note 1, at 1356 n.4. 
sion. When combined with the already existing considerable confusion about the precise parameters of the treaty power, the net result is the constitutional equivalent of a Serbonian Bog.

\section{Semantic Confusion and the Normal Workings of THE TREATY POWER}

\section{A. Of Power Sharing and Other Tall-Tales}

Much of the conceptual muddle regarding the exact parameters of the constitutional prerogatives of the two political branches in the treaty-making area is attributable to semantic confusion largely created by the resurgence of ultra-whiggish propaganda. ${ }^{3}$ The precise use of words is always important in legal analysis and is particularly crucial in this area. Thus, Professor Koplow's main thesis, "that the power to create treaty obligations for the United States is shared between the Executive and Legislative Branches" and that "[o]nce an interpretation of a treaty has become entrenched in United States domestic law through the joint action of the Senate and President, it cannot be altered unilaterally by a reinterpretation sponsored by either branch alone"4 is based on an assumption that the treaty-making power is "shared" by the President and the Senate. This assumption, while not technically wrong, is misleading. ${ }^{.}$The constitutional reality is quite different.

The Framers distributed governmental powers among the three branches subject only to such checks as the qualified veto of the President and the advice and consent function of the Senate. ${ }^{6}$ In reality, although the term is used widely, the Framers did not place identical duties "concurrently" in two or three branches of government. In other words, the responsibilities of the three branches do not "overlap";

3 Professor Rostow in his article Once More Into the Breach: The War Powers Resolution Revisited, 21 VAL. U.L. REv. 1, 2 (1986), termed modern advocaters of legislative supremacy, particularly in the field of foreign relations, "ultra-whigs," a term he credits to Edward Corwin.

- Koplow, supra note 1 , at 1357.

- Koplow compounds the problem by observing that "[t]reaty law is a classic example of Justice Jackson's second category, the 'twilight zone' of concurrent, uncertain Executive and Legislative authority and shared functions." Koplow, supra note 1, at 1394 (citing Youngstown Sheet \& Tube Co. v. Sawyer, 343 U.S. 579 (1952)). In fact, both political branches have very clear and distinct treaty-relevant powers and the "twilight zone" in this area exists only in the minds of those arguing for increased legislative prerogatives, dissatisfied with the constitutionally-mandated allocation of powers.

- See generally E. Corwin, The President's Control of Foreign RelaTroNs (1917) (describing the structural role of the presidential veto and the advice and consent function of the Senate in the scheme of separation of powers). 
strictly speaking, there are no "shared" or blended powers. " Instead, while power to accomplish certain ends itself may be "mixed," in James Madison's terms (that is, divided between branches such as the treaty power is divided between the Executive and the Senate), each branch has distinct constitutional duties and prerogatives. Thus, it follows that the treaty power is not a constitutional equivalent of an open market. Instead, both the Executive and the Senate wield certain specific responsibilities in this area and, as explained below, the responsibility to interpret treaties is solely vested in the President by the Constitution.

\section{B. Constitutional Treaty Makers: The President, The Senate, and Foreign States}

For over two hundred years it generally has been recognized that the President possesses inherent and plenary constitutional authority in foreign affairs. The principle textual source for the President's wide discretion to act for the nation in foreign affairs is Article II, section 1 of the Constitution, which simply provides that "[t]he executive Power shall be vested in a President of the United States of America." This clause has been recognized to confer upon the President plenary authority to represent the United States ${ }^{8}$ and to pursue its interests outside the borders of the country, subject only to the explicit limits set forth in the text of the Constitution and to such statutory limitations as the Constitution permits Congress to impose by exercising one or more of its enumerated powers. Thus, Thomas Jefferson, who generally disfavored an expansive view of presidential power, in construing the Constitution, wrote that " $[t]$ he transaction of business with foreign nations is executive altogether; it belongs, then, to the head of that depart-

7 See Burns \& Markman, Understanding the Separation of Powers, 7 PACE L. REv. 575, 580 (1987). A system of shared or overlapping powers would be one of constitutional anarchy. As Professor Corwin stated, "if the legislative and executive branches both possessed the power of recognizing the independence of a foreign nation, and one branch should declare its independence, then, since they are coordinate, how could the problem be solved by the judicial branch?" E. Conwin, supra note 6, at 36 . While the President possesses inherent constitutional authority to conduct foreign policy, Congress' power in foreign affairs (the relationship between nations) is limited primarily to "post-hoc" checks on presidential initiatives, such as the Senate failure to consent to a treaty, the "power of the purse," and ultimately the impeachment power.

8 Thus, the President has been termed the "sole organ of the nation in its external relations." E. Corwin, The President: Office AND Powers, 1787-1984, at 207-08 (1984) (quoting remarks of John Marshall as a member of the House of Representatives in 1799 discussing the Jay Treaty); see also United States v. Curtiss-Wright Export Corp., 299 U.S. 304, 319-20 (1936) (describing the President's authority in foreign affairs plenary and named the President the "sole organ of the federal government in the field of international relations"). 
ment, except as to such portions of it as are specifically submitted to the senate. Exceptions are to be construed strictly. . . ." The executive power, therefore, includes all the discretion traditionally available to any sovereign in foreign relations, except in so far as discretion is placed in another branch of the government by the Constitution.

Arguably, treaty-making is the paramount foreign relation power because it binds whole sovereign nations to future courses of action. Historically, this treaty-making power has been seen as quintessentially an executive function. Thus, to John Locke, who greatly influenced the Framers of our Constitution, the "federative" or foreign affairs power, which comprises in part "leagues and alliances, and all transactions with all persons and communities without the commonwealth," 10 should be wielded by the Executive because a legislature "is not always in being and is usually too numerous, and ... too slow for the dispatch requisite to execution" and because "it is impossible to foresee and so by laws to provide for all accidents and necessities that may concern the public."11 The Baron de Montesquieu, another political writer widely read by the Framers, wrote that the treaty-making power is one of the governmental powers that should be wholly and exclusively Executive. ${ }^{12}$

Because treaties under the United States Constitution have the force of law, ${ }^{13}$ however, the Framers believed it was inappropriate to vest a republican executive with unfettered treaty-making power. To Hamilton, therefore, treaties under the Constitution were neither wholly an executive nor legislative function. ${ }^{14}$

5 Writings of Thomas JefFerson 161 (Ford ed. 1895). 1952).

${ }^{10} \mathrm{~J}$. Locke, The Second Treatise of Government 83 (Bobbs-Merril ed.

ii $I d$. at 92.

12 See Montesquieu, The Spirit of the Laws 151-53 (Hafner ed. 1949). Of course, in elaborating on the British constitution, the power to make treaties and alliances with foreign states typically was seen by commentators, such as William Blackstone, as traditionally comprising part of the "King's Prerogative." See W. BLACKStone, Commentaries on the Laws of ENGLand *244-45.

1s Article VI, section 2 ("Supremacy Clause") of the Constitution makes "Laws of the United States" and "Treaties" the "Supreme Law of the Land" and the "Judges in every state ... bound thereby." U.S. ConST. art. VI, §2. Treaties were included in the Supremacy Clause because state legislatures and courts were refusing to enforce or give effect to federal treaties negotiated by the Congress pursuant to the old Articles of Confederation - to the detriment of American relations with foreign powers. See P. KuRland \& R. LeRner, The Founders' Constitution 589-92 (1987). See generally F. MARKS, INDEPENDENCE ON TRIAL: Foreign AfFairs and THE MaKing of THE ConSTITUTION (1986) (arguing that foreign policy considerations were of overwhelming significance to the Framers).

14 See The Federalist No. 75, at 450 (A. Hamilton) (C. Rossiter ed. 1961).

The power of making treaties is plainly neither the one nor the other. It relates neither to the execution of the subsisting laws, nor to the inaction 
The constitutional solution to this republican paradox was to place treaty-making power in the hands of the President, conditioned and checked by the Senate's advice and consent role. The President would play the lead and unhindered role in the conditional negotiation of treaties, and the Senate would assure that the treaty would be in the nation's interest by recommending modifications ("advice") or by refusing to assent ("consent"). In other words, it was the view of the Framers that the "joint possession of the [treaty] power . . . by the President and Senate would afford a greater prospect of security, than the separate possession of it by either of them."15

More succinctly, with regard to treaty-making, it was the intent of the Framers that both the Senate and the President have distinct and different powers bearing on this area. The President negotiates a treaty with foreign powers and submits it to the Senate for advice and consent.

Significantly, the advice component of the "advice and consent" provision does not demand senatorial participation in all phases of treaty-formation, such as negotiation. While Washington thought that the Senate could constitutionally function as an Executive or privy council providing advice to a President, as President he believed that

of new ones, and still less to an exertion of the common strength. Its objects are contracts with foreign nations, which have the force of the law, but derive it from the obligations of the good faith. They are not rules prescribed by the sovereign to the subject, but agreements between sovereign and sovereign.

The power in question seems therefore to form a distinct department, and to belong properly neither to the legislative nor to the executive branch. The qualities elsewhere detailed, and indispensable in the management of foreign relations, point out the executive as the most fit agent in those transactions; while the vast importance of the trust, and the operation of treaties as laws, plead strongly for the participation of the whole or part of the legislative body in the office of making them.

Id.

Hamilton's mention of the "qualities elsewhere detailed" refers to John Jay's discussion of the executive role in treaty-making in The Federalist No. 64. Like Hamilton, Jay believed that the President was the agency most suited to treaty formation because in the negotiation of treaties:

. . perfect secrecy and immediate dispatch are sometimes requisite. There are cases where the most useful intelligence may be obtained, if the persons possessing it can be relieved from apprehensions of discovery. . . . there doubtless are many ... who would not confide in that of the senate and still less in that of a large public assembly. The convention has done well therefore in so disposing of the power of making treaties, that although the President must in forming them act by the advice and consent of the Senate, yet he will be able to manage the business of intelligence in such manner as prudence may suggest.

Id. No. 64, at 392-393 (J. Jay).

1s Id. No. 75, at 505 (A. Hamilton). 
the Constitution did not require consultation with the Senate prior to treaty-formation. ${ }^{16}$ In order to protect the secrecy of sensitive negotiations and avoid delay accompanying long drawn out debates in the Senate, early in his first administration Washington, upon the constitutional advice of leading members of his cabinet, changed his initial practice and took treaties to the Senate after they were made. ${ }^{17}$ Unilateral negotiations by the President with foreign powers and Indian tribes left unchanged the Senate's power to advise and consent after negotiations. The Senate could conditionally approve treaties by advancing "advice" by way of amendments. Having obtained that advice and consent, the President then has the option of either ratifying or not ratifying the treaty. The Senate, in addition to consenting to or rejecting the treaty as submitted by the President, has the option of predicating its consent upon changes in the treaty's terms. ${ }^{18}$ In fact, from the early days of the Republic, the Senate, rather than merely accepting or rejecting a treaty submitted by the President, began to request as a condition to its advice and consent that particular changes or clarifications to the treaty provisions be made.

The fact that the Senate may change a proposed treaty does not mean, however, that Senate can work its will in any way it pleases. Instead, the proper way for the Senate to attach a particular understanding to a treaty is to set forth that understanding in the resolution by which the Senate gives its advice and consent to the treaty's ratification and to state in that resolution that its approval is given on the basis of that understanding. ${ }^{19}$ And in order to ensure that any understanding or condition on which the Senate conditions its consent is given effect, the President normally must take steps to obtain and record the agreement of the other party to that understanding or condition. ${ }^{20}$

16 See R. Hayden, The Senate and Treaties, 1789-1817, at 11-40, 58-94 (1970). Thus, Professor Koplow's assertion that the early practice under the Constitution was for the President to consult the Senate prior and during negotiations is technically correct but quite misleading.

17 See P. KuRland \& R. LeRner, supra note 13, at 62-63.

18 See Fourteen Diamond Rings v. United States, 183 U.S. 176, 183 (1901) (Senate may refuse to ratify treaty or make ratification conditional upon adoption of certain amendments, but may not introduce new terms into the treaty without the consent of the other treaty partner); Haver v. Yaker, 76 U.S. (9 Wall.) 32, 35 (1869) (Senate need not accept treaty as a whole, but may modify it).

18 See Restatement (Third) of the Foreign Relations Law of the UnIted STATES $§ 314(2)$ (1987) [hereinafter Restatement 3D]. According to the Restatement $3 d$, "[w]hen the Senate gives its advice and consent to a treaty on the basis of a particular understanding of its meaning, the President, if he makes the treaty, must do so on the basis of the Senate's understanding." Id.

20 The Restatement 3d states:

Since the President can make a treaty only with the advice and consent of 
More specifically, if the President determines that the treaty, as a matter of international law, can be interpreted in accordance with the understanding reflected in the Senate ratification proceedings, he may either include that understanding in the instrument of ratification (or otherwise call it to the other party's attention) or not include it, as he sees fit. ${ }^{21}$ Conversely, if the President decides that under international law, the treaty cannot be so interpreted, he then has no authority to ratify the treaty unless he accompanies it by a reservation conforming to the Senate's understanding. ${ }^{22}$ In that event, of course, the treaty will

the Senate, he must give effect to conditions imposed by the Senate on its consent. The President generally includes a verbatim recitation of any proposed reservation, statement of understanding, or other declaration relevant to the application or interpretation of the treaty contained in the Senate resolution of consent, both in the instrument notifying the other state or the depositary of United States ratification or accession and in the proclamation of the treaty. ... The President may also communicate a Senate qualification separately.

Id. at $\S 314$, comment $\mathrm{b}$. The only time the President need not take steps in this situation is if the treaty, as a matter of international law, cannot be interpreted at variance with the Senate's understanding.

${ }_{21}$ The Restatement (Second) of the Foreign Relations Law of the United States, which the Restatement 3d, supra note 19, does not purport to alter in this respect, is even more explicit on this point. It states:

When the resolution by which the Senate gives its advice and consent to the ratification of a treaty states that its approval is given on the basis of an understanding that is set forth or incorporated in the resolution, the President, if he ratified the treaty, must include the Senate's statement of understanding in the instrument of ratification or otherwise make it clear that the assent of the United States is subject to the understanding unless, as a matter of international law, the treaty cannot be interpreted otherwise than as stated in the understanding.

Restatement (Second) of the Foreign Relations Law of the United States $\S 133(2)$ (1965) [hereinafter REsTATEMENT 2D] (emphasis added).

In determining that a treaty, as a matter of international law, can be interpreted consistent with a Senate understanding, established by the ratification record but not expressed in the Senate's resolution of advice and consent, the President merely must decide that such an understanding is $a$ permissible interpretation. He need not determine that it is the only permissible interpretation, nor does he foreclose a future President from deciding that another interpretation is also permissible as a matter of international law.

22 See United States v. Stuart, 57 U.S.L.W. 4263, 4269 (Feb. 28, 1989)(Scalia, J., concurring specially) (stating that "[i]f they [Senate's conditions] are not agreed to by the President, his only constitutionally permissible course is to decline to ratify the treaty, and his ratification without the conditions would presumably provide the basis for impeachment"); see also ResTATEMENT 2D, supra note 21 , at $\$ 133$ (3). The $R e$ statement $3 d$ omits, without explanation, the principle enunciated in $\S 133(3)$ of the Restatement 2d. Section 314(2) of the Restatement $3 d$ can be read to mean that the President, if he makes a treaty, must do so on the basis of any understanding on which the Senate based its advice and consent, even though such understanding is not contained in the Senate's resolution, but is merely derivable from the record of Senate deliberations. This view represents a dramatic break with the rule established in the Restatement $2 d$, and there were no developments in legal precedent since its date of 
not take effect unless the other party accepts that reservation.

The obvious purpose of this procedure is to allow the other treaty party to review the understanding attached by the Senate and decide whether to accept the Senate's understanding or to object to it. Should the other party assent to the treaty subject to the Senate's understanding, there then can be no doubt that the United States and the other party share the same understanding of the treaty. ${ }^{23}$ By the same token, if the other party objects to the Senate's understanding, there can be no doubt that the United States and the other party do not share the same understanding of the treaty. According to the Restatement (Third): "If a reservation is attached [to a bilateral agreement] at ratification, it constitutes in effect a rejection of the original tentative agreement and a counter-offer of a new agreement. The other party must accept the agreement as revised by the reservation. . . ."24

Absent such an acceptance, of course, no meeting of minds between the treaty parties occurred, ${ }^{25}$ and either negotiations will be bro-

publication in 1965 to justify such a revision. Moreover, in marked contrast to other sections of the Restatement $3 d$ which, to the extent that they differ from the Restatement $2 d$, offer the justification for the change, $\S 314(2)$ does nothing of the kind. Thus, the legal weight of $\S 314(2)$ is somewhat suspect. Yet, even the comments to the Restatement $3 d$ concede that the President has the prerogative to decide whether statements in the Senate record represent a general understanding of the Senate; if he finds they do not, he need not respect them. See RESTATEMENT 3D, supra note 19, at $\S 314$, comment d. Justice Scalia, in his concurring opinion in Stuart, also strongly criticized the position taken by Restatement 3d, noting that it

must be regarded as a proposal for change rather than a restatement of existing doctrine, since the commentary refers to not a single case, of this or any other United States court, that has employed the practice [of inferring the treaty's meaning from the record of Senate debate on that treaty]. The current version of the Restatement provides no explanation for (or even acknowledgment of) this curiosity.

Stuart, 57 U.S.L.W. at 4270 (Scalia, J., concurring specially).

${ }^{23}$ The Court has indicated this, for example, in Northwestern Bands of Shoshone Indians v. United States, 324 U.S. 335, 350-54 (1945).

24 Restatement 3D, supra note 19 , at $\S 313$, comment $f$.

26 Senator Nunn (Democrat of Georgia), a leading advocate of the Senate's alleged constitutional prerogative to control presidential treaty interpretation, tries to evade this problem by claiming that there is no need to communicate Senate interpretation to the other treaty party; the onus is on them to object. Nunn notes that because the Soviets read our Senate committee reports and testimony, if they do not object to the interpretations put forth in the process of obtaining the Senate's advice and consent, they supposedly are bound by them. See Sofaer, The Treaty Power, 43 U. Miami L. REv. 101, 102 (1988).

Despite this peculiar view of estoppel in the treaty context, Nunn's views are contrary to established legal authority. There is well settled case law that any treaty provision adopted by the Senate to qualify or construe the treaty, if excluded from the instruments of ratification and not communicated to the other treaty parties, is not binding. See Sullivan v. Kidd, 254 U.S. 433, 442 (1921); Fourteen Diamond Rings v. United States, 183 U.S. 176, 182 (1901); New York Indians v. Kidd, 254 U.S. 433, 422 (1897); Kelly v. S.A. Belge, 242 F. Supp. 129, 141 (E.D.N.Y. 1965). 
ken without a treaty being brought into force or negotiations will continue until the parties have agreed on its terms, including any understandings on which the United States Senate still may condition its consent to the treaty. Significantly, the precise term ("reservation," "understanding," "condition" or the like) used by the Senate in its resolution of advice and consent is not dispositive; if the Senate intends to affect the legal obligations of the United States under the treaty, its action will have the same effect as a reservation, no matter what word is used. ${ }^{26}$

To ensure that Senate conditions of this sort are binding on both parties, "in bilateral treaties, the United States has made it a practice to include in the ratification a statement by each party expressly stipulating its acceptance of the reservations, declarations, understandings, etc., of the other."27 This practice serves to ensure that the treaty to which the Senate has contested is the same treaty that the other contracting party has accepted and hence - in the oft-repeated phrase of the present Democratic Senate leadership - the treaty made by the President is that treaty on which there has been "a meeting of the minds between the Senate and the President." Put another way, the President can make only that treaty to which the Senate has consented.

The Senate's role, however, does not extend to the implementation of a treaty and its consequent "interpretation." As Professor Koplow himself correctly observes, once a treaty is ratified, "the President, as Chief Executive, bears the responsibility for faithfully implementing it." ${ }^{28} \mathrm{He}$ alone determines in the process of implementing an international agreement what are the international obligations of the United

28 See RESTATEMENT 3D, supra note 19 , at $\S 313$, comment $g$. In the view of the authors, however, some of the present doctrinal confusion is attributable to the typology developed by the Senate Foreign Relations Committee in 1979 in dealing with the ratification of the SALT II Treaty. At the time, the Committee was concerned with the then existing imprecise nomenclature describing various conditions imposed by the Senate. Accordingly, it divided all Senate imposed conditions into three categories:

Category I provisions do not involve any formal notice to the other party; Category II provisions are formally communicated to the other party as official United States government positions but do not require acceptance or acknowledgement by the other party; Category III provisions require explicit agreement by the other party before the treaty can come into force.

Koplow, supra note 1, at 1401 (citing Senate Foreign Relations CoMm., RePORT oN THE SALT II TREATy, S. ExeC. ReP. No. 14, 96th Cong., 1st Sess. 68-69, 167-73 (1979)); see also Glennon, The Senate Role in Treaty Ratification, 77 AM. J. INT'L L. 257,266 (1983). While the Committee's typology was certainly clear, it did spawn the mistaken notion that the Senate can impose domestically binding treaty conditions that need not be communicated formally to the other treaty party and do not affect United States international obligations.

${ }^{27}$ Restatement 3D, supra note 19 , at $\S 314$, reporter's note 1 .

${ }^{28}$ Koplow, supra note 1, at 1395. 
States. It is solely the President, as the "sole organ" of the United States in foreign affairs, who " interprets" " treaties." ${ }^{29}$ The President, under the Constitution, "has authority to determine the interpretation of an international agreement to be asserted by the United States in its relations with other states."30 The Senate's role is limited strictly to advice and consent - to conditioning consent to the treaty by proposing modifications or to assenting to its ratification as originally submitted by the President.

The Senate has essentially no constitutional role in the subsequent interpretation of the implications under international law of treaties to which it earlier gave advice and consent. ${ }^{31}$ As the Supreme Court stated

29 See id. at 1396. In the Pacificus Letters, written by Hamilton to support President Washington's unilateral proclamation of neutrality in the war between France and Britain in 1793, Hamilton argued that the Executive (and not Congress) was the proper agency to make such a proclamation because it is the "organ of intercourse between the nation and foreign nations" and the "interpreter of the national treaties .. . between government and government"; because it is "the branch that executed the law and treaties," the branch that is in "command and disposition of public forces." E. CoRWIN, supra note 6 , at 10 .

30 RESTATEMENT 3D, supra note 19 , at $\S 326(1)$.

31 There is also the matter of the treaty's interpretation under domestic law. Here again, under the Constitution, the President is not bound automatically by a Senate understanding that is reflected merely in the record of the Senate's deliberations but is not included in the Senate's resolution of advice and consent. To the contrary, any such Senate understanding has no greater weight in the interpretation of a treaty as domestic law than the record of legislative history has in the interpretation of a statute. See Restatement 3D, supra note 19 , at $\S 314$, comment $d$. Such an understanding, if it can be gleaned from the record of Senate deliberations, is to be taken into account, but it certainly is not dispositive. See id. It should be noted that the courts also "interpret" treaties, but only in the context of an actual "case or controversy," which usually implicates private rights. Moreover, the courts, when presented with a need to construe treaties, traditionally have accorded considerable deference to the interpretation of the Executive Branch. See Sullivan v. Kidd, 254 U.S. 433, 442 (1921).

While the question of the construction of treaties is judicial in its nature, and courts when called upon to act should be careful to see that international engagements are faithfully kept and observed, the construction placed upon the treaty before us and consistently adhered to by the Executive Department of the Government, charged with the supervision of our foreign relations, should be given much weight.

Id.

As stated in the Restatement 3d, "Courts in the United States have final authority to interpret an international agreement for purposes of applying it as law in the United States, but will give great weight to an interpretation made by the Executive Branch." Restatement 3D, supra note 19 , at $\S 326(2)$; see also A. Sofaer, War, Foreign AfFaIRs, AND Constitutional PowER 127-29 (1976). In general, the courts have recognized that there is only one narrowly construed limitation on the Executive's discretion to interpret provisions of a treaty or statute. The Supreme Court observed in Japan Whaling Association v. American Cetacean Society, 478 U.S. 221 (1986), that only a clearly and unambiguously expressed congressional intent to construe a particular statutory provision in a certain way deprives the Executive of flexibility in construing that provision. See id. at 234-40; see also Chevron U.S.A. v. Natural Resources 
in the leading case of Fourteen Diamond Rings $v$. United States," "the meaning of the treaty cannot be controlled by subsequent explanations of some of those who may have voted to ratify it." ${ }^{\prime 33}$ The same principle of construction applies to statutes. Thus, in construing legislation passed by Congress, the courts generally have refused to consider subsequent explanations proffered by members of Congress as to what the original legislative intent of Congress was or what the statute at issue was designed to accomplish. ${ }^{34}$

It follows from the above that the President, in exercising the duties of his office, from time to time may "reinterpret" the meaning of a treaty under international law or interpret particular treaty provisions differently from prior Presidents, provided that in so doing he does not contravene an explicit understanding expressed in the Senate's resolution of advice and consent and accepted by the other treaty party. Indeed, Presidents have done so on more than one occasion. ${ }^{35}$

Contrary to this existing case law, professor Koplow maintains that Congress also " interprets" " treaties when "[i]t assesses, as a domestic political and legal matter, what the document requires and what additional action should be taken within the constitutional scope of leg-

Defense Council, 467 U.S. 837, 859-66 (1986). In the case of the 1972 ABM Treaty, there are no indications, precise or otherwise, of how the Senate intended to construe the provisions of the ABM Treaty dealing with "exotic" ABM devices.

${ }^{32} 183$ U.S. 176 (1901). For further useful discussion of the general impact of post-enactment congressional actions on statutory interpretation, see Koplow, supra note 1 , at 1407 n.219.

ss Fourteen Diamond Rings, 183 U.S. at 180 . An identical view is expressed by Professor Louis Henkin, who wrote in 1972: "Attempts by the Senate to withdraw, modify, or interpret its consent after a treaty is ratified have no legal weight, nor has the Senate any authoritative voice in interpreting a treaty by terminating it." L. HENKIN, Foreign AfFaIRS AND THE Constitution 136 (1972).

3t The Senate Foreign Relations Committee is well aware of the case law in this area. Thus, it could not possibly assert that it had a right to interpret the ABM Treaty. Instead, the committee modestly described its efforts (culminating.in S. Res. 167, 100th Cong., 1st Sess. (1987)) as amounting to no more than listing certain constitutional principles pertaining to the ABM Treaty and outlining conclusions that stem therefrom. This description, however, is highly disingenuous. Despite the committee's denial, its efforts amount to nothing less than an attempt to interpret the ABM Treaty an activity in which it is proscribed from engaging by the Supreme Court's jurisprudence. An analogous effort is represented by the Byrd Amendment to the 1988 INF Treaty, insofar as the Senate seems to arrogate to itself the power to determine whether a given treaty provision is subject to common understanding and what is the meaning of that particular understanding. See 134 CoNG. REC. S6937 (daily ed. May 27, 1988) (stating the Byrd Amendment).

${ }^{35}$ See generally A. SOFAER, supra note 31 (describing the various historical practices of Presidents). In fact, in the face of the need to protect the security of the infant American republic, President Washington unilaterally "reinterpreted" the Treaty of Paris of 1783 by de facto abrogation of that Treaty's defensive alliance between the United States and France. See G. Wills, Cincinnatus 87-103 (1984). 
islative powers to promote United States interests."36 This activity, however, is not "interpretation" in the technical sense, which is determining, in the process of implementing a treaty, the international obligations of the United States. The Senate only "interprets" treaties as anyone who reads an instrument must "interpret" it by giving meaning to the words used. Certainly, during the advice and consent process, the Senate must construe the terms of the treaty in determining whether or not to grant its consent. Or, as Professor Koplow rightly notes, the entire Congress may construe a treaty where, for instance, it is not "selfexecuting" and requires legislation to carry out its terms. Construing the requirements of the treaty in the course of the legislative process, however, is very different from determining what the obligations of the United States are for purposes of international or domestic law and attempting to bind the President to that understanding.

In short, the law with regard to treaty interpretation is clear and straightforward: (1) only the President may definitively interpret the meaning of a treaty as a matter of international law; (2) the President can construe the treaty as a matter of domestic law, but only the courts may definitively interpret its meaning as a matter of domestic law in the context of specific cases and controversies; (3) the Senate has no authority to interpret a treaty, once it is ratified, as a matter of either international or domestic law; (4) if the Senate's resolution of advice and consent states a particular understanding of an as yet unratified treaty, the President may ratify the treaty subject to that understanding only, and the treaty will take effect only if the other treaty party accepts that understanding; (5) where, however, the Senate resolution contains no understanding, but the record of Senate deliberations establishes that the Senate attaches a particular meaning to the as yet unratified treaty, the President has the discretion to decide what, if any, international legal effect the Senate intended its record to have and to take appropriate action, or no action; (6) a Senate understanding not contained in the Senate's resolution of advice and consent and not formally accepted by the other high contracting party is not controlling in the interpretation of the treaty as a matter of either international or domestic law. 


\section{SACRED Mysteries and TREaties?: \\ United States Domestic v. International Obligations}

\section{A. When do Minds Meet and Obligations Become Entrenched?}

Professor Koplow has joined the ranks of a number of scholars who have strained to stitch together some colorable legal and constitutional arguments to support a claim of legislative supremacy with regard to treaty-making. Their arguments differ in specifics, but are based generally upon a theory of the nature of a treaty that is little short of the mystical. With misplaced theological enthusiasm they argue that a treaty has two natures, a domestic nature as well as an international nature, the profane and the divine. As Professor Michael Glennon notes, "the United States' domestic obligations under a given international agreement need not necessarily correspond to its international obligations." ${ }^{37} \mathrm{He}$ argues further that whatever the international meaning of a treaty might be, for domestic purposes the President only can ratify the treaty to which the Senate consented, adopting the position of the Senate Foreign Relations Committee in Resolution 167 - the ABM Treaty Interpretation Resolution. ${ }^{38}$

The Committee's ABM Report deals with the problem in a startling fashion: it criticizes the Executive Branch's position on treaty interpretation, articulated by the State Department's Legal Advisor, Abraham Sofaer, and asserts that the official statements of the Soviet Union delivered through its authorized representatives during the ABM Treaty negotiations are essentially irrelevant to determining the treaty's meaning under domestic law:

The Legal Advisor's principal premise is the unequivocal assertion that a treaty's meaning derives from communications between the parties. This is true - under international law. But it is not true under United States law.

.... The President cannot cause the United States to become a party to a treaty to which the Senate has not given its advice and consent. Nor can he cause the United States to

s7 Glennon, Interpreting "Interpretation": The President, the Senate, and When Treaty Interpretation Becomes Treaty Making, 20 U.C. Davis L. REv. 913, 914 (1987).

${ }^{38}$ See id. at 916 (quoting S. Res. 167, 100th Cong., 1st Sess. § 2(2)(A) (1987)). This resolution grew from the March-April 1987 hearings held jointly by the Senate Foreign Relations and Judiciary Committees. While the Senate Foreign Relations Committee subsequently favorably reported Resolution 167 , it has never been passed either by the full Senate or by the House. A conceptually similar provision, dubbed the "Byrd Amendment," was inserted into the 1988 INF Treaty. See supra note 34. 
become a party to a treaty different from the one to which the Senate has given its advice and consent. Thus, if the United States is to adhere to a given treaty, it can adhere only to the treaty concerning which a "meeting of the minds" has occurred between the President and Senate. ${ }^{38}$

If the Committee merely intended to say that a President may bring into force only that version of a treaty to which the Senate has given its advice and consent, the point would be unobjectionable. But the Committee is saying much more. It is asserting that the Executive Branch is bound forever by a version of a treaty to which the Senate believes it gave its advice and consent, or in the case of the ABM Treaty, by that version to which the Senate Foreign Relations Committee sixteen years later says the Senate advised and consented, whether or not it is the version to which the other treaty party agreed.

It is striking that the debate has reached a point where the questionable doctrinal assumption that a treaty has two natures, one domestic and one international, imposing differing obligations upon the United States, merits so little discussion. Professor Koplow, while cautioning that "very little is clear in this field,"40 merely notes that domestic law can impose "tougher restrictions on the United States than those compelled by our negotiating partners under the treaty." $13 \mathrm{He}$ then devotes himself to the practical problems of identifying when a particular senatorial "interpretation" has become a binding species of domestic law.

Yet, the views of the Foreign Relations Committee, Professor Koplow, Professor Glennon, and others proceed from a fundamentally flawed premise. In Professor Koplow's view, an unwritten Senate understanding, so long as it is adequately "entrenched," becomes a part of the treaty and the law of the land. It is well accepted under the norms of international law, however, that to be binding, such "understandings" must be "formulated in writing and communicated to the other party or parties to the treaty," ${ }^{42}$ a point not strongly challenged even by the legislative supremacists. ${ }^{43}$ According to Glennon, however, because the treaty has a domestic as well as an international nature, and they

39 ABM TReATY REPORT, supra note 2, at 70.

10 Koplow, supra note 1 , at 1380.

41 . at 1390 . Interestingly enough, Professor Koplow displays a perfectly sound appreciation of the intricacies involved in creating a binding treaty obligation under international law. See id. at 1387-89. It is his analysis of the nexus between international and domestic legal obligations that falls woefully short of the mark.

12 Glennon, supra note 26 , at 259.

43 But see supra note 25 and accompanying text. 
are not necessarily identical, the Senate allegedly need not formalize its understanding of the treaty's meaning.44 As Professor Glennon argues, "[a]t issue here is the President's obligation vis-a-vis the Senate."45 Yet, as argued above, treaties have no independent domestic legal status sep-

4S See Glennon, supra note 37, at 918. It also should be acknowledged that the majority opinion in United States v. Stuart, 57 U.S.L.W. 4263 (Feb. 28, 1989), contains a footnote asserting that Senate debates on a treaty "do not occur behind closed doors out of earshot of treaty partners, nor are preratification Senate reports kept under seal." Id. at 4267 n.7. The implication of this language is that, at least in the absence of objection by the other treaty party, an informal Senate understanding may suffice to modify United States international treaty obligations - a view identical to that expressed by Senator Nunn in the contexts of the ABM Treaty debate. Undoubtedly, Supreme Court opinions are entitled to considerable, albeit not unquestioned, deference. Several factors, however, diminish the authority of the above-referenced Stuart language. To begin, the footnote in issue is clearly dictum since the analysis of the plain meaning of the United States-Canadian tax treaty was fully sufficient to support the Court's decision. Second, having reviewed the briefs submitted to the Court and the record of the oral arguments in Stuart, we have found no evidence that the issue of whether, as a matter of constitutional law, a treaty may generate domestic obligations at variance with international obligations assumed by the United States was briefed by the parties or considered by the Court. Thus, what we have is another regrettable instance of the Court casually opining in dicta on a major constitutional issue, without the benefit of any adversarial argument to illuminate the underlying constitutional issues. Justice Scalia's special concurrence in Stuart notes all of these problems.

45 Glennon, supra note 37 , at 918 . The notion that there are domestic obligations that can be imposed by the Senate also is articulated in RESTATEMENT 3D, supra note 19 , at $\S 314$, comment $e$, and $\S 303$, comment $d$. This view represents a departure from the Restatement $2 d$, which does not contain any such notion. Regrettably, the Restatement $3 d$ provides no support for the proposition it asserts, that purely domestic obligations can be imposed on the United States by the Senate in the process of treatymaking. Given the conspicuous lack of authority, this assertion at most reflects the views of Columbia Law School Professor Louis Henkin, who served as the Chief Reporter for the American Law Institute's Restatement 3d. To be sure, Professor Henkin is an eminent legal scholar, whose views are entitled to some deference. Nevertheless, that deference need not be automatic. It should be noted, however, that in contrast to some commentators on the treaty power, Professor Henkin has been remarkably consistent in this view. As far as we can determine, his views regarding the permissibility of additional "domestic" obligations stemming from an international treaty date back to his involvement in Power Auth. v. Federal Power Comm'n, 247 F.2d 538 (D.C. Cir.), vacated and remanded with directions to dismiss as moot sub. nom. American Public Power Ass'n v. Power Auth., 355 U.S. 64 (1957). In that instance, Henkin sided with the plaintiff, the Power Authority of the State of New York. Two other eminent scholars and Columbia University law professors, Philip C. Jessup and Oliver J. Lissitzyn, backed the defendant. The major issue was whether a condition of purely domestic import that was added by the Senate to the 1950 United States-Canada Niagara Treaty constituted a valid reservation. As Henkin himself notes in a post-decision law review article, the court adopted the position of Jessup and Lissitzyn:

"[T]he so-called Senate 'reservation' was a mere colorable use of the treaty-making power; was not a treaty reservation within the legal meaning of that term; is not in legal contemplation a part of the Treaty with Canada; and is invalid as an attempt to amend or repeal in part the Federal Power Act."

Henkin, The Treaty Makers and the Law Makers: The Niagara Reservation, 56 Colum. L. Rev. 1151, 1151 (1956) (quoting Power Auth., 247 F.2d at 541). 
arate from their status as international agreements; ${ }^{46}$ there are not two sets of obligations, one domestic and one international. Any treaty creates only one set of international obligations, which may have a specific domestic impact; the United States may be obligated to take or refrain from certain domestic actions only in order to comply with its international obligations.

\section{B. The Supremacy Clause Revisited}

Turning to a related point, it is true that treaties are the "supreme Law of the Land," but the argument that any written provision of a treaty, debate in the Senate, or testimony before the Senate concerning a treaty provision is also the supreme law of the land by extension is clearly spurious. The Supremacy Glause is the wrong edifice upon which to base the two-treaty construct suggested by Professor Koplow and others. ${ }^{47}$ It grants neither the President nor the Senate any additional treaty-making authority, and does not purport to fashion another form of domestic law-making. As the Court of Appeals for the District of Columbia Circuit emphasized in Goldwater v. Carter, ${ }^{48}$ treaties are "sui generis," not just another law. "[I]t is thus well to distinguish between treaty-making as an international act and the consequences which flow domestically from such act." 48

The original purpose of granting treaties the status of "supreme law of the land" was not to create an additional vehicle for domestic legislation, one excluding the House of Representatives. Rather, as stated above, the Framers' objective was to enable the federal government to comply with the international obligations of the United States without interference from the states. ${ }^{50}$ This apparently had been a serious problem during the Confederation period. To cite one interesting example, in 1783 an individual sued in the New York courts under a state statute allowing dispossessed patriots to sue loyalists for compen-

${ }^{46}$ As Professor Henkin has written:

The responsibility of the President to take care that international law and U.S. treaties are faithfully executed derives from and depends on their status as law in the United States, a status derived from and dependent on their character as international obligations of the United States. For example, if a treaty is void, or it terminates, the treaty is not, or ceases to be, law in the United States.

Henkin, International Law as Law in the United States, 82 MrcH. L. Rev. 1555, 1568 (1984) (emphasis added).

4 See Koplow, supra note 1, at 1389.

48617 F.2d 697 (D.C. Cir. 1979).

49 Id. at 705 .

so See Rague, The Reservation Power and the Connally Amendment, 11 J. INT'L L. \& POL. 323, 325-26 (1978). 
sation. The young Alexander Hamilton represented the defendant, arguing that the state statute in issue was invalid because the Treaty of Paris provided a mutual release of such claims. The state court ruled against Hamilton's client, noting that it was required to follow the state law although it did opine that the treaty probably was controlling. ${ }^{51}$

The Framers made treaties the supreme law of the land precisely to avoid the repetition of such controversies. Once entered by the United States through the process provided in the Constitution, they take precedence over state laws and constitutions. ${ }^{52}$ Neither individual states nor citizens may take actions putting the United States in violation of its international obligations. The treaty-making process is not an independent means of domestic lawmaking, elevating part of the treatymaking process not actually included verbatim in the text of the treaty, such as testimony, to the level of law. It does not allow the President and the Senate to circumvent the House of Representatives. ${ }^{53}$ As the Goldwater court cautioned,

[t]he fact that the Constitution, statutes, and treaties are all listed in the Supremacy Clause as being superior to any form of state law does not mean that the making and unmaking of treaties can be analogized to the making and unmaking of domestic statutes any more than it can be analogized to the making or unmaking of a constitutional amendment. ${ }^{54}$

51 See Westen, The Place of Foreign Treaties in the Courts of the United States: A Reply to Louis Henkin, 101 HaRv. L. REv. 511, 514 n.14 (1987).

${ }_{62}$ While the Constitution itself does not so specify, the Supreme Court also has held that treaties take precedence over prior inconsistent federal statutes. "The language of the Supremacy Clause of the Constitution has been read to imply that laws and treaties of the United States are not only supreme over state law, but are equal in status and authority to each other." Henkin, supra note 46, at 1563 n.31. Here, the latter in time rules.

${ }^{53}$ See INS v. Chadha, 462 U.S. 919 (1983) (emphasizing the functional role of bicameralism in separation of powers).

B4 Goldwater v. Carter, 617 F.2d 697, 705 (D.C. Cir. 1979). The profound difference between a legislative process and a treaty process also is demonstrated easily by the fact that the President has unilateral authority to terminate a treaty, thus ending both domestic and international obligations stemming from that treaty. See L. HeNkIN, supra note 33 at $169-71$ (stating that the better view is that the President alone, not the President and the Senate, may abrogate treaties); $c f$. Charlton v. Kelly, 229 U.S. 447, 473-76 (1912) (noting that the President, as spokesman for the United States, may determine whether treaty provisions have lapsed or are abrogated by a breach of the other high-contracting party). In contrast, the President cannot unilaterally terminate a statute. The domestic obligations are entirely dependent upon the international obligations of the treaty. If, for example, the international obligations of a treaty are repudiated, the domestic obligations also are dissolved. As noted by Professor Henkin:

The responsibility of the President to take care that international law and U.S. treaties are faithfully executed derives from and depends on their status as law in the United States, a status derived from and dependent on 


\section{How the Laws are Made and Not Made}

Arguing reductio ad absurdum, the key point of why the treatymaking process cannot be used to increase the purely domestic legal obligations of the United States also can be illustrated by demonstrating the profoundly unconstitutional results of such an arrangement. First, the "two treaty" argument would lead to the unacceptable result that the Senate could introduce new terms into a treaty and make those terms binding on the President, even though the other treaty party never agreed to those terms. Indeed, under this approach the Senate could obtain such a result merely by sprinkling the ratification record with floor speeches, hearing testimony and the like, on the basis of which one could argue later that the ratification debate supported the purported Senate understanding at issue. Such an approach would amount to unilateral senatorial treaty-making by ambush and is clearly impermissible. As Mr. Justice Brown stated in concurring with the majority decision in Fourteen Diamond Rings v. United States:

In its essence [a treaty] is a contract. It differs from an ordinary contract only in being an agreement between independent states instead of private parties. . . . Obviously the treaty must contain the whole contract between the parties, and the power of the Senate is limited to ratification of such terms as have already been agreed upon between the President, acting for the United States, and the commissioners of the other contracting power. The Senate has no right to ratify the treaty and introduce new terms into it, which shall be obligatory upon the other power, although it may refuse its ratification, or make such ratification conditional upon the adoption of amendments to the treaty. ${ }^{55}$

Second, such an approach would make a mockery of the constitutional principles governing the enactment of legislation. Professor Koplow appears to be quite oblivious to the constitutional deficiency of the arguments advanced to support the theory of asymmetrical treaty obligations. He merely seems to assume that such a duality is a self-

their character as international obligations of the United States. For example, if a treaty is void, or if it terminates, the treaty is not, or ceases to be, law in the United States.

Henkin, supra note 46, at 1568 (emphasis added); see also Rague, supra note 50, at 337-38. The principle that the President unilaterally may abrogate a treaty and that once abrogated, all domestic treaty obligations terminate is implicit in the court's ruling in Goldwater, 617 F.2d at 705.

ss 183 U.S. 176, 182-83 (1901) (Brown, J., concurring). 
evident proposition and primarily concerns himself with a secondary issue: how the Senate, the President, or both, can create or modify a domestic treaty obligation without altering the international bargain involved. Koplow's answer is that an interpretation, clarification, or understanding of the treaty terms, however manifested and however disconnected from what the parties to the treaty agreed, acquires the status of domestic law once they become "entrenched":

Despite these practical problems of establishing the existence and terms of an unwritten Senate understanding, once such an understanding has been shown to exist, there is no conceptual difficulty in assessing its legal status. The Senate's understandings and conditions, however evidenced, are fully binding upon the President once the treaty is "made." The Senate's view of the treaty, whether explicit or implicit, is an integral part of the treaty, and the President cannot proceed to ratification on any other terms. ${ }^{.6}$

The implications of this astounding statement are far-reaching indeed. Professor Koplow's theory confuses the domestic impact of a treaty with domestic law-making and would be nothing short of revolutionary if it were accepted. In fact, the Constitution does not recognize a variety of means of domestic lawmaking, it recognizes only one: the ordinary legislative process where bills are passed by the House of Representatives and the Senate and signed by the President (or passed over his veto). There are enactments other than statutes that may have the force and effect of law, such as the rules and regulations of executive agencies. ${ }^{57}$ Professor Koplow, however, posits a system where the President or the Senate, acting alone, create domestic legal obligations that would bind the President in his implementation of the treaty. The Constitution provides for no such process. ${ }^{58}$ Indeed, it is ironic that

se Koplow, supra note 1, at 1404-05.

67 The courts also are said to "make law" and it is also true that the President is said to "make law" when entering an executive agreement. See Henkin, supra note 46, at 1565; see also United States v. Belmont, 301 U.S. 324 (1937) (an executive agreement is equivalent to a treaty for purposes of domestic law). Such agreements are not legislation, but like rules and regulations only enjoy the force and effect of law, and the extent of their ability to override prior statutes has never been adjudicated definitively. See Henkin, supra note 46, at 1565 n.36.

${ }_{58}$ The only other path by which binding legal obligations can be enacted is through a constitutional amendment. Such an amendment, however, would require the concurrence of both Houses of Congress, as well as the acceptance by two-thirds of all the states. An identical view has been expressed by Senator Roth, who noted, during the floor debate on the Byrd Amendment, that:

A condition is either binding or it is not. For a condition to be legally binding it must be part of a treaty, statute, or constitutional amendment. 
modern day "ultra-whigs," masquerading as defenders of legislative power, seem prepared to flout the fundamental principle of American republicanism - that the only valid laws are those properly enacted by Congress, in the exercise of its enumerated powers, and brought before the President, who either acquiesces or vetoes the legislation.

If the Senate Foreign Relations Committee is to be believed, however, the Senate alone could make legislation by tacking on any provisions it wished to a treaty or by inserting an "understanding" into the ratification debate that effectively added new provisions to the treaty, albeit purely of domestic import. ${ }^{59}$ Under such a scheme the Senate

The pending [Byrd] amendment is none of those. Therefore, it is not bind-

ing. It is not binding, it is not binding internally or domestically.

135 Cong. Rec. S6767 (daily ed. May 26, 1988).

50 The view that a treaty condition, which is of a purely domestic import and is not backed by a matching international legal obligation, lacks binding legal force was expressed by the Court of Appeals for the District of Columbia Circuit. See Power Auth. v. Federal Power Comm'n, 247 F.2d 538 (D.C. Cir.), vacated and remanded with directions to dismiss as moot sub nom. American Public Power Ass'n v. Power Auth., 355 U.S. 64 (1957); see also supra note 45. Significantly, the written condition in issue was in writing and was communicated to the other treaty partner. But see Rainbow Navigation, Inc. v. Department of the Navy, 686 F. Supp. 354, 358-59 (D.D.C. 1988). The Rainbow Navigation case is relied upon heavily on by Professor Koplow. These authors do not have problems with Koplow's description of the case. Indeed, Judge Green did find that certain oral assurances regarding the implementation of a 1980 United States-Iceland treaty, offered to the Senate during the advice and consent process, were binding on the Executive Branch, precluding it from interpreting the treaty in an inconsistent manner. It is also true that Judge Green assailed the alleged position of the government "that whatever is said to the Senate does not mean anything." Koplow, supra note 1 , at 1400.

The impact of the case, however, is not as revolutionary as Koplow suggests. To begin, the plaintiff clearly was entitled to prevail on an alternative ground, insofar as the Department of the Navy's interpretation of the treaty was clearly untenable. More fundamentally, there is no evidence that the constitutional problems inherent in the two treaty system were considered by Judge Green. Rainbow Navigation is an example of a trial judge seizing an opportunity to proffer constitutionally spurious dictum, despite the lack of proper adversarial arguments.

In a subsequent decision in Rainbow Navigation, decided in November of 1988, the government essentially conceded the validity of Judge Green's dictum, stating that:

authoritative Executive branch representations concerning the meaning of a Treaty which form part of the basis upon which the Senate gives advice and consent are entitled to be accorded binding weight as a matter of domestic constitutional law, and the Executive branch fully accepts that it is bound by such statements.

Rainbow Navigation, Inc. v. Department of the Navy, 699 F. Supp. 339, 343 (D.D.C. 1988) (quoting Defendant's Reply Brief and Opposition to Plaintiff's Cross-Motion for Summary Judgment at 2 n.2). Possibly the government's "change of heart" is related to the political firestorm arising from the Byrd Amendment and INF Treaty debates in the summer of 1988. See Rivkin, The GOP Must Share the Blame for the Byrd Amendment, Wall ST. J., June 15, 1988, at A23, col. 3; see also United States v. Stuart, 57 U.S.L.W. 4263, 4270 (Feb. 28, 1989) (Scalia, J., concurring specially) (criticizing the decision in Rainbow Navigation). 
could completely cut the House of Representatives from the legislative process. For that matter, the President himself could use such a scheme as a ruse for bypassing the House with legislation that he expected to win Senate approval but that was unlikely to pass muster in the House. It is interesting to speculate, for example, what the reaction of congressional Democrats would have been had President Reagan decided, for example, to conclude a treaty with Honduras containing an extra domestic provision permitting the United States Government to support the Nicaraguan Democratic Resistance. In fact, one easily can envision a treaty loaded like a Christmas tree with all sorts of domestic provisions - something akin to the regrettably popular omnibus continuing budget resolutions that sweep everything into their vortex. The profoundly unconstitutional nature of such arrangements should be selfevident.

\section{How Much Legislative Intent is Enough?}

Once the interpretation is "entrenched," Professor Koplow asserts, "[t]he Executive's attempt to reinterpret established aspects of a treaty is an unconstitutional usurpation of power." ${ }^{160}$ Quite aside from the constitutionally flawed nature of Koplow's basic assumption, to wit, the permissibility of asymmetrical domestic and international obligations, his scheme for determining whether a particular "interpretation" has become "entrenched," and therefore a part of domestic law, is also very problematic. No attempt will be made here to analyze each of Professor Koplow's eight factors to be considered in determining whether a particular interpretation has become entrenched. ${ }^{61}$ Admittedly, he states that none would be necessarily dispositive alone. It is evident, however, that in his view some are more influential than others. First, Professor Koplow places particular emphasis upon the statements made during the debate on the treaty by "key Senators," stating that if they paid particular attention to the matter in question, and if it seemed to be an important factor in their decisions how to vote, then this understanding "should be more entrenched in the law." ${ }^{\text {"2 }}$ Here it is possible to draw "meaningful inferences" from casual comments and even from silence itself: "a very small number of explicit comments . . . should be pow-

60 Koplow, supra note 1, at 1357.

61 These include such factors as senatorial statements at the time advice and consent is given, statements to the Senate by the Executive during the advice and consent process, support in the text and negotiation record of the treaty, the attitude of the other party, and subsequent practice. See Koplow, supra note 1, at 1419-25.

${ }^{62}$ Id. at 1419. 
erful evidence."Bs

Unfortunately, Professor Koplow's method fails to take account of how legal obligations actually are brought into being. According to Koplow's statutory interpretation method, "[i]f Congress had a specific intention and a court can deduce from these secondary sources what that intent was, then that intent is binding and becomes part of the statute or treaty." ${ }^{\prime 64}$ This purely subjective approach to statutory interpretation ignores the realities, not to mention the legalities, of the legislative process. Even if intent can be proven beyond all doubt, it does not control. It is the actual language of the enacted legislation that is the law, not the unenacted intent of the legislators. ${ }^{65}$ Koplow's infatuation with legislative history admirably points to the very reason that courts are wary of its use and proceed cautiously. Under the best of circumstances, as Justice Scalia aptly noted, legislative history is a "frail substitute for bicameral vote upon the text of a law and its presentment to the President."

Moreover, ordinarily legislative history is far from clear and is often contradictory. As Justice Jackson once observed, "[i]t is a poor cause that cannot find some plausible support in legislative history." Indeed, the assumption underlying the use of all legislative history is that it may reflect legislative intent. This further presumes that there was some "intent" upon a particular issue. As in the case of the ABM Treaty, however, when a subsequent controversy arises it is probably precisely because the Senate did not address the particular issue. An analysis following Professor Koplow's theory then must search for a few fragments of legislative history and ultimately is reduced to reliance upon the views of a few isolated members.

Clearly, the individual statements of a few Senators, however much they may care about the point in issue or however much they may repeat their views for the record, are not dispositive or even very helpful. Only the Senate as a whole, or at least two-thirds of that body, can insist that a reservation or an understanding be attached to a treaty. Here Professor Koplow's system appears to exalt the opinions and

${ }^{63}$ Id. at $1420-21$.

64 Id. at 1406.

65 The question of why the unenacted intent of the Senate has no legal weight was reviewed at length in a claims court case. See Coplin v. United States, 6 Cl. Ct. 115 (1984), rev'd on other grounds, 761 F.2d 688 (1985), affd sub.nom. 107 S. Ct. 347 (1986). The Coplin opinion, authored by Judge Alex Kozinski, contains excellent language describing various historical instances in which the Senate's unenacted intent was ignored in interpreting treaty obligations. See id. at 144-45.

${ }_{66}^{66}$ Thompson v. Thompson, 108 S. Ct. 513, 523 (1988) (Scalia, J., concurring).

67 Jackson, Problems of Statutory Interpretation, 8 F.R.D. 121, 125 (1948). 
wishes of individual Senators over that of the entire chamber, views that may well have been rejected by their colleagues. As Judge Alex Kozinski of the United States Court of Appeals for the Ninth Circuit wrote not long ago, "[s]tray comments by individual legislators, not otherwise supported by statutory language or committee reports, cannot be attributed to the full body that voted on the bill. The opposite inference is far more likely." 68

The second of Professor Koplow's factors is statements made to the Senate by Executive Branch witnesses during the ratification process. These, Professor Koplow notes, "can be especially compelling in generating a senatorial understanding or interpretation." section-by-section analysis presented to the Senate and informal statements such as the statements of outside experts will be important. Again, this reverts to an estoppel argument.

Under this construct, representations made to the Senate by the Executive during the advice and consent process become a binding part of the treaty. This view has a certain superficial appeal: if the Executive has led the Senate to believe that a treaty means one thing and the Senate grants its consent based upon these representations, then he should not be able to change his interpretation later. ${ }^{20}$ The creation of an extra-constitutional lawmaking process scheme of senatorial control of treaty interpretation, however, is unnecessary to deal with those instances where the President has misled the Senate.

\section{Political Process v. Constitutional Shortcuts}

\section{A. The Senate's Strawmen}

The legislative supremacists are particularly adept at constructing a truly ingenious "parade of horribles." For instance, in addition to the ever present specter of a nefarious President seeking to obtain the Senate's consent by trickery favored by Professor Koplow, Professor Glennon paints a bleak picture of future treaty negotiation and ratification:

Hereafter the Senate would feel compelled to demand the negotiating record to every treaty to satisfy that nothing

${ }^{68}$ In Re Kelly, 841 F.2d 908, 912 n.3 (9th Cir. 1988).

68 Koplow, supra note 1 , at 1421 .

${ }^{70}$ The authors acknowledge that this view has been expressed in the Rainbow Navigation case. See Rainbow Navigation, Inc. v. Department of the Navy, 686 F. Supp. 354, 358-59 (D.D.C. 1988). As discussed supra note 59, in their view, the case, while correctly decided from a factual standpoint, takes an incorrect position with regard to the impact of oral assurances by Executive Branch witnesses during the treaty ratification on the Executive's subsequent ability to interpret the treaty. 
therein contradicted the public assurances of the Administration. Or, the Senate would feel compelled to incorporate into its approval of every treaty a reservation for every jot and title in the Administration's public statements as to what the treaty means, lest those statements later be disavowed in favor of a secret negotiating record. The impact on American diplomacy would be devastating. ${ }^{71}$

Likewise, Koplow asserts that:

Many in the Senate felt that the Sofaer Doctrine presented unpalatable choices: if authoritative administration testimony was not automatically binding, then, in order to guarantee that any particular point of interpretation would be reliable in the future, the Senate might have to recite its understanding with a condition or other explicit declaration in the resolution of ratification. There might be a great many points where the Senate would want to insist upon entrenching a durable interpretation. Accordingly, dozens or even hundreds of such conditions might be needed to expressly affix to the resolution of ratification virtually everything that Executive Branch officials had asserted to the Congress.

Moreover, under these circumstances, the Senate might additionally feel obligated to scrutinize the entire classified negotiating record itself, to ensure that the Executive Branch testimony fairly and accurately represented the true nature of the United States-Soviet understandings. This would require elaborate inspection of voluminous, disparate negotiating documents, a laborious and time-consuming function that the Senate would not be well-equipped to perform. ${ }^{72}$

Koplow's basic argument is that the President cannot be free to "reinterpret the international obligations of the United States at will,

"Glennon, supra note 37, at 919 . Glennon also asserts that the Administration's position is "that the meaning of the [ABM] treaty in force in 1987 was the meaning on which the negotiators had secretly agreed - not the meaning described to the Senate in 1972 by Administration spokesmen . . . ." Id. at 915 . This, however, profoundly misrepresents the Reagan Administration's position insofar as it has never claimed that there was some secret understanding on exotic ABM devices reached by the United States and Soviet negotiators and deliberately withheld from the Senate. Instead, what has happened is that the Nixon Administration, itself partially confused on this issue, used some careless language in testifying before the Senate. There was never any effort, however, to mislead the Senate.

72 Koplow, supra note 1 , at 1377. 
since this would allow him to circumvent the advice and consent process."73 As Glennon expounds upon this theme, the President exceeds his constitutional authority when he adopts an interpretation different from that of the Senate that consented to the treaty: "[s]uch an act is thus not truly an 'interpretation' at all - it is a violation of the Treaty Clause." ${ }^{44}$ They argue that if the President is free to reinterpret a treaty, then he could mislead the Senate as to its meaning and obtain advice and consent under false pretenses. ${ }^{75}$

It is worth noting that these arguments are designed to guard against a threat that is likely never to arise. The chances of a President deliberately misleading the Senate regarding the meaning of a treaty are little short of fantastic. The very openness of the process, the number of people involved in the negotiation and ratification of a treaty, not to mention the attitude of the other party, make such a scenario virtually impossible. Indeed, the present controversy was not sparked by charges that either President Nixon or President Reagan misled the Senate regarding the interpretation of the ABM treaty. The issue arose from unforeseen changes of circumstance and technology, some less than precise treaty language (reflecting the failure of the parties in 1972 to agree on the issue), and an honest difference of opinion on whether America should be defended against nuclear attack. Such changes of circumstance cannot be guarded against because by their very nature: they are unforeseeable. Essentially, adopting the construct advocated by the ultra-whigs only supports the Senate's ability, under the guise of treaty interpretation, to force its foreign policy preferences upon the President at a later date; it does nothing to bring a miscreant Chief Executive to account.

\section{B. How to Do Things Right - A Primer for the Senate}

In the final analysis, the Congress in general, and the Senate in

73 Id. at 1418.

74 Glennon, supra note 37 , at 919 .

75 Even though he takes pains to disavow it, Koplow ultimately depends upon an "estoppel" argument. He asserts that "the bottom line" is that the Senate has a role in treaty-making, and that "the Senate must be able to depend upon authoritative executive representations." Koplow, supra note 1 , at 1427 . This is understandable. The principle that one should not profit from a misrepresentation is embedded deeply in our jurisprudence - it is upon this foundation that all estoppel law is based. Unfortunately, these principles have no relevance in the context of treaty-making and interpretation. The Constitution provides no means by which the Senate legally can hold the President to representations made to it about the meaning of a treaty. To be sure, the Executive who lies to Congress may be subject to impeachment or to political retaliation, but there is no process by which these misrepresentations, or the understandings they may engender, can become law. 
particular, is not without recourse to ensure through proper constitutional means that its own interpretation of a particular treaty will prevail. ${ }^{76}$ Clearly, the Senate may insist on a particular interpretation of a treaty before giving its advice and consent. This process has long been recognized in the Senate's attaching "reservations" and "understandings" to a particular treaty. As Professor Glennon himself wrote only five years ago, if the other party accepts these conditions, "both the text of the treaty and the Senate's conditions take effect internationally and, if the treaty is self-executing, become the law of the land."'77 If these conditions are not accepted by the other party, the President may not proceed to ratification and the treaty is rejected. Of course, this process requires careful legislative work - a task that has become increasingly unpopular these days.

In essence, the Senate has two legitimate ways to deal with a treaty. First, it can approve the treaty as is, without paying too much attention to the fine print, and rely on the Executive's good sense to have struck a good bargain for the United States. In the current atmosphere of intense partisanship and executive-congressional tensions, however, not many important treaties are likely to be handled this way. An equally legitimate alternative is for the Senate to roll up its sleeves and to cross all the " $t$ "s and dot all the "i"s in the treaty. ${ }^{78}$ If they mistrust the Executive and want to limit his flexibility in interpreting the treaty, they are free to attach an endless host of conditions, clarifications and understandings. ${ }^{7 \theta}$ There is a price to be paid, of course:

${ }^{78}$ See United States v. Stuart, 57 U.S.L.W. 4263, 4269 n. 11. (Feb. 28, 1989).

77 Glennon, supra note 26, at 263.

78 Glennon complains about the difficulty involved in "assembling a single, complete, and cohesive negotiating record" which the Senate could review. Glennon, supra 37, at 917. This, indeed, may be true of any legislative history. But it is difficult to see why being aware of this problem and also realizing that, for purposes of establishing American international legal obligations, the negotiating record and the text of the treaty do control, the Senate should choose to shift the onus of examining that record entirely to the Executive Branch and opt to rely blindly on Executive Branch testimony which is based on that very same negotiating record. Moreover, the Senate considers at most a dozen treaties per year, not an unduly heavy burden for even the most meticulous legislators.

${ }_{78}$ Glennon also attacks the supposed illogical nature of the claim that the only way the Senate can make its view count is through an explicit written reservation, noting that a treaty section whose meaning is obvious is unlikely to cause the Senate to attach any written understandings. See id. at 918. Here again, Glennon seems to assume an extreme dishonesty on the part of the Executive, who allegedly is likely to interpret crystal clear and obvious treaty provisions in ways utterly incompatible with their plain meaning. This situation, in fact, has never arisen. But even more fundamentally, there is no neat constitutional shortcut to resolving the problem of an Executive who flouts his oath to execute faithfully the laws and purposefully perverts the meaning of a treaty or a statute. If a violation is blatant and serious enough, then impeachment is the appropriate remedy. Short of that, the appropriate approach is for Congress 
Senate creative efforts have to be communicated to and accepted by the other treaty party. A treaty or two might be scuttled in the process and the United States might suffer international embarrassment. Yet, such efforts are perfectly legitimate from a constitutional standpoint.

What is completely illegitimate, however, is to search for unconstitutional shortcuts. Yet this is precisely the approach preferred by legislative supremacists: create an all-purpose legislative history, treat every statement by the Executive Branch witnesses as binding, and declare yourself to be the ultimate arbiter of what the original "entrenched" interpretation is. As a result, the ultimate responsibility is avoided while ultimate power is retained. Under the guise of assuring fidelity to the original interpretation, the Senate can block any efforts by the Executive Branch pertaining to or impacting upon the subject covered by the treaty, and Fourteen Diamond Rings is avoided neatly. The net result is the unfettered power to control the Executive without any need to perform tedious legislative work or incur political costs - a veritable senatorial Shangriola.

The complaints of the critics that without the two-treaty construct, the Senate would be a helpless victim of the Executive are also disingenuous. Even after the treaty has been ratified, the Senate at any time may join with the House of Representatives and force a President to accept its interpretation of a treaty (assuming there are sufficient votes to override the President's veto). Professor Koplow himself admits that "[o]rdinary legislation probably could have provided a suitable battleground,"80 and that this may be the "superior"81 method. Nor is the Congress completely unfamiliar with how to tie the Executive's hands on the treaty interpretation issue through the use of separate legislation. This is precisely what it did by prescribing the de facto compliance with the narrow interpretation of the ABM Treaty in the Fiscal Year 1988-89 National Defense Authorization Act. ${ }^{82}$ And it is certainly the "superior" method since it is constitutionally proper. ${ }^{83}$ In general,

to penalize the Executive through the political process and by taking the case to the American people.

80 Koplow supra note 1, at 1428.

81 Id.

82 National Defense Authorization Act for Fiscal Years 1988 and 1989, Pub. L. No. $100-180, \S 225,101$ Stat. 1019, 1056 (1987). Here, de facto compliance with the narrow interpretation of the ABM Treaty was secured by limiting permissible SDI tests to those listed in a specific Defense Department report. All these tests were consistent with the narrow interpretation.

83 To be sure, there are some limitations on the ability of Congress to force the Executive to comply, as a matter of domestic law, with a particular international undertaking. At the very least, there must be a properly ratified treaty to start. For example, in 1982 the Senate and the House sought to pass a joint resolution which was intended to formalize the President's announced decision to continue to comply with the 
the legislative authority of Congress gives it ample tools with which to engage an overreaching Chief Executive. As Judge Bork has remarked, members of Congress who are dissatisfied with the President's performance traditionally have proceeded by "oversight hearings, budgetary restrictions, political struggle, appeals to the electorate, and the like."84 Further, if it can be shown that the President purposefully deceived the Senate, this well may be grounds for impeachment. Finally, advice and consent on a treaty achieved by fraudulent means may be invalid and lead to a subsequent dissolution of United States treaty obligations. ${ }^{85}$ The fact that this whole process is unwieldy and cannot always ensure a Senate triumph is not a valid objection. These are the means provided in the Constitution.

It is important to realize that when the President or his representatives provide certain assurances about the treaty's interpretation or related policy issues to the Senate during the treaty ratification, they are engaging in a purely political exercise. Inducements and promises are very much a part of the normal legislative process, and treaty-making is no exception. Both the Executive and Congress regularly extract political commitments from each other to secure favorable action on legislation. Some of these promises are kept; others fall by the wayside. The key point is that the enforcement of political promises also ought to be done through the give and take, carrot and stick, of the political process. $^{86}$ Regrettably, the Senate in the treaty power dispute and Con-

provisions of the unratified SALT II Treaty. The President's so-called interim compliance with the SALT II restraints was undertaken jointly with the Soviet Union and was meant to apply while the negotiations on further cuts in strategic nuclear weapons, the Strategic Arms Reduction Talks, were proceeding. The Executive Branch, however, never intended to turn its policy declaration into binding legal obligations. Congressional efforts to give the force of law to the President's statement of policy were criticized strongly. As noted in a report by the Senate Judiciary Committee's Subcommittee on Separation of Powers, "the attempt to give treaty obligations the force of law by the approval of simple majorities of both Houses of Congress instead of by constitutionally mandated two-thirds majority of the Senate violates the exclusive advice and consent function of the Senate prescribed by the Constitution." Senate Subcomm. on SeParation of Powers, Report On S.J. Res. 212 to the Senate Comm. on the Judiciary, 97th Cong., 2d Sess. 4 (1982).

84 Barnes v. Kline, 759 F.2d 21, 45 (D.C. Cir. 1985) (Bork, J., dissenting).

85 The issue of whether fraud perpetrated in the course of treaty negotiation or ratification negates American international and domestic obligations is a difficult one, and Koplow's discussion of it is quite instructive. See Koplow, supra note 1, at 141617. Certainly, if the other side participates in or is aware of the fraud being committed by the President, the treaty is null and void. If the fraud was committed without any knowledge or involvement of the other party, the treaty probably remains binding as a matter of international law. In that case, however, the proper course of action is for the United States to repudiate the treaty - a step fully within its sovereign prerogatives and fully justified under the international law principle of rebus sic stantibus.

${ }^{88}$ Koplow himself indirectly acknowledges that numerous assurances proferred by 
gress in many other confrontations with the Executive have manifested a clear desire to avoid the rigors and costs of political combat, preferring instead to cloak themselves in a pseudo-constitutional garb.

Legislative supremacists also would do well to acknowledge that legislative perfection, defined as a process that invariably and forever guarantees policy outcomes to the liking of every legislator, is unattain$a^{a b l e}{ }^{87}$ and has never been a part of the constitutional scheme. Thus, a statute or a treaty, no matter how careful the legislative process, might contain ambiguous provisions and, because of mistakes or unforeseen circumstances, might well fail to effect the policy goals the President and the legislators intended to effectuate. The proper recourses in such instances are to rely on the Executive to use his judgment and in good faith to execute the laws to meet new policy challenges as they arise. Should it become necessary, the Congress also may have to go back to the legislative drawing board or the negotiating table to enact new statutes or to negotiate a new treaty. It is, however, certainly inappropriate to adopt such legislative shortcuts as the creation of amorphous legislative history, to be used by the Senate in the case of treaties, or by Congress in the case of statutes to dictate to the President how to execute the duties of his office. To the ultra-whigs, this approach may be politically expedient, yet it is neither constitutional nor good public policy because it subverts the very essence of the American democratic legislative and political process.

the Executive Branch to the Senate during the ratification process are political in nature and carry no legal force when he cites a 1974 colloquy by the Honorable Frederick Charles Ikle, then Director of the United States Arms Control and Disarmament Agency, proferred in connection with the Senate ratification of the 1972 Biological Weapons Convention. See id. at 1360-61.

${ }_{87}$ Even Senator Nunn, not known for his modesty in asserting the reach of the Senate's constitutional prerogatives, acknowledges that "as we in the Senate well know, writing clear law is a worthy goal but one not easily attained." 133 CoNG. REC. S3172 (daily ed. Mar. 13, 1987). 


$$
\text { . }
$$

